\title{
EKSPRESIVISME HARIAN LEO TOLSTOY DALAM KESENIAN JEMBLUNG BANYUMAS
}

\author{
Nurratri Widya Pangestika \\ SMP Negeri 1 Kesugihan \\ ratrywhidya@gmail.com
}

\begin{abstract}
Abstrak
Kesenian Jemblung merupakan salah satu jenis folklor lisan yang hadir dengan media utamanya adalah tutur (oral action). Karakteristik kesenian Jemblung sebagai seni tutur terlihat ketika para pemain menggunakan beberapa makanan maupun minuman sebagai media komunikasi ekspresi di setiap adegan untuk merepresentasikan sebuah tokoh dalam cerita. Penelitian ini menggunakan metode kualitatif interpretatif. Teknik pengumpulan data terdiri dari observasi, wawancara, dan studi dokumen. Proses pengabsahan data menggunakan kriteria derajat kepercayaan (kredibilitas).Teknik triangulasi yang digunakan pada penelitian ini adalah triangulasi sumber. Proses analisis dilakukan dengan model siklus yang dimulai dari pengumpulan data, reduksi dan mengklarifikasi, menyimpulkan dan menginterpretasikan semua informasi secara selektif. Hasil penelitian menunjukkan bahwa hakiki sebuah seni ekspresivisme melibatkan emosi yang bersifat positif yakni rasa menyenangkan dengan simbol interaksi komunikasi berupa senggakan. Sebagai kriteria seni baik, pertunjukan Jemblung dapat memberikan nilai atau pesan-pesan moral yang bersifat religius, gigih, berani, kuat, berjiwa kepemimpinan, dan tanggung jawab.
\end{abstract}

Kata kunci: ekspresivisme; jemblung; moral; senggakan

\begin{abstract}
Jemblung art is one type of oral folklore that comes with the main media is speech (oral action). Characteristics of Jemblung art as speech art are seen when the players use some food and drinks as a medium of communication expression in each scene to represent a character in the story. This research uses interpretative qualitative methods. Data collection techniques consist of observation, interviews, and document studies. The data validation process uses criteria of the degree of trust (credibility). The triangulation technique used in this study is source triangulation. The analysis process is carried out with a cycle model that starts from data collection, reduction and clarifying, concluding and interpreting all information selectively. The results showed that the essence of an expression art involves positive emotions, which is a sense of fun with a symbol of communication interaction in the form of senggakan. As a criterion for good art, Jemblung performances can provide moral values or messages that are religious, persistent, brave, strong, leadership-minded, and responsible.
\end{abstract}

Keywords: expression; jemblung; moral; senggakan

\section{Pendahuluan}

Masyarakat dan kebudayaan merupakan suatu kesatuan yang memiliki hubungan satu sama lain. Salah satu perwujudan unsur kebudayaan adalah benda-benda yang diciptakan oleh manusia berupa karya seni. Manifestasi seni yang diciptakan oleh manusia berupa seni rupa, seni musik, seni tari, seni sastra, seni tutur, dan seni teater yang didalamnya senantiasa mengandung pesan, fungsi, maupun nilai tertentu kepada penikmatnya yang diwujudkan melalui sebuah pertunjukan. Seni pertunjukan merupakan bagian dari kehidupan masyarakat sebagai salah satu kebutuhan, dilaksanakan secara 
kolektif dan dipertunjukan di depan penonton agar memperoleh hiburan serta pengalaman estetis.

Suatu seni pertunjukan sekurang-kurangnya mensyaratkan adanya materi kegiatan kesenian (tari, musik, teater), seniman atau pelaku seni yang melakukan kegiatan berkesenian, dan penonton yang menyaksikan kegiatan kesenian (Jazuli, 2016, p. 35). Suatu kebahagiaan ketika seni pertunjukan hadir sebagai ungkapan imajinasi kreatif manusia. Hal tersebut dapat dipahami karena seni pertunjukan mengandung nilai-nilai. Nilai yang terkandung dalam seni pertunjukan merupakan nilai dasar kodrati yang dikenal dengan istilah nilai estetis.

Nilai estetis merupakan penghayatan seseorang terhadap karya seni yang dibutuhkan melalui sebuah kemampuan, interpretasi maupun penafsiran di bidang estetis. Nilai keindahan tidak diukur dari nilai-nilai non-tradisi tetapi berdasarkan rasa keindahan menurut masyarakatnya (Harwanto, 2018, p. 43). Sehubungan dengan hal tersebut, dalam memahami sebuah nilai estetis terdapat sebuah subjek dan objek yang tidak dapat dipisahkan. Menurut Junaedi (2017, p. 81) bahwa subjek estetis merupakan subjek atau seseorang yang menikmati atau menciptakan objek estetis. Dengan kata lain, subjek estetis dapat berupa spektator maupun kreator. Spektator juga disebut penikmat, penonton, pemirsa atau pengamat, sedangkan kreator adalah pembuat atau pencipta. Adapun kreator yang bertindak secara sungguh-sungguh dalam penciptaan objek estetis disebut seniman.

Tidak seperti kebanyakan individu yang hanya mengalami pengalaman estetis, seorang seniman mentransmisi pengalaman estetisnya melalui sebuah karya seni pertunjukan, dari pengalaman tersebut sebuah karya seni dapat dinikmati oleh orang lain. Keistimewaan seni pertunjukan sebagai eskpresi perasaan emosi manusia akan memperluas komunikasi menjadi persentuhan subyektif yakni pesan dan pengalaman seniman kepada penikmat, penonton, maupun pengamat. Serangkaian gagasan yang berhubungan dengan seni dan emosi dirajut serta ditata dalam konsep estetika yang dikenal dengan istilah ekspresivisme. Pandangan ekspresivisme dapat diketahui dan ditelusuri dari gerakan Romantisme sampai dengan para filsuf klasik seperti Aristoteles, tetapi sebagai gagasan yang relatif sistematis ekspresivisme baru eksis pada paruh kedua abad ke-19 (Blocker, 1979, p. 95). Aliran ekspresivisme dibangun berdasarkan dua asumsi yaitu sesuatu yang dilakukan seniman adalah mengekspresikan emosinya dan ekspresi merupakan sumber nilai estetis suatu karya seni (Sheppard, 1987, p. 10). 
Jerome Stolnitz dalam bukunya Aesthetic and Philosophy of Art Criticism (Stolnitz, 1960) mengelompokkan ekspresivisme atau emosionalisme ke dalam dua jenis yaitu ekspresivisme yang menekankan pada personalitas dengan tokohnya Veron dan ekspresivisme yang menekankan komunikasi emosi atau disebut sebagai ekspresivisme harian dengan tokohnya Leo Tolstoy dan Ducass. Dalam kerangka estetika, Tolstoy membangun teori hakiki seni berdasarkan tiga asumsi yaitu 1) seni merupakan suatu bentuk komunikasi, 2) apa yang dikomunikasikan adalah perasaan (feeling), dan 3) konsep seni memiliki pengertian luas dan sempit (Tolstoy, 1969, p. 201). Kemunculan ide baru sebagai bagian dari proses kreatif seniman merupakan hasil interaksi antar manusia dengan manusia dan manusia dengan lingkungannya. Karya seni akan selalu terkait dengan hal-hal yang telah ada sebelumnya, baik bersifat natural maupun kultural.

Manifestasi perubahan bentuk kesenian merupakan hakiki seni ekspresivisme yang menekankan pada ekspresi perasaan dan emosi seniman. Pandangan Tolstoy tentang ekspresivisme seni dibangun berdasarkan dua teori yang saling berhubungan yaitu teori estetika dan teori moral. Dengan estetika, Tolstoy ingin menunjukan kapan sesuatu layak disebut seni atau tidak dan dengan moral ia berusaha mengevaluasi kualitas atau nilai dari suatu karya seni. Proses perubahan kesenian sebagai sebuah gagasan modern menciptakan realitas baru tentang ekspresivisme yang dipengaruhi oleh proses perubahan sosial dalam masyarakatnya tidak terkecuali perubahan kesenian yang ada di Banyumas.

Keanekaragaman kesenian di Banyumas terdiri atas seni pertunjukan rakyat yang memiliki fungsi-fungsi tertentu terkait dengan kehidupan masyarakat pendukungnya. Kesenian Jemblung merupakan perwujudan sifat kerakyatan masyarakat Banyumas yang berakar pada kebudayaan yang hidup di lingkungan masyarakat agraris yang relatif jauh dari kehidupan perkotaan. Kesenian Jemblung merupakan salah satu jenis folklor lisan dengan media utamanya adalah tutur (oral action). Iringan mulut atau oral action dari pemain Jemblung merupakan imitasi dari aransemen gendhing Jawa yang lazim disajikan melalui perangkat gamelan. Kata Jemblung merupakan jarwadhosok dari kata jejere budaya luhung yang artinya cerita budaya yang luhur. Dengan mengandalkan kekuatan oral action sebagai media ungkap, memungkinkan Jemblung tampil komunikatif, egaliter, menarik, lucu, unik, dan dinamis dalam setiap pertunjukannya. 

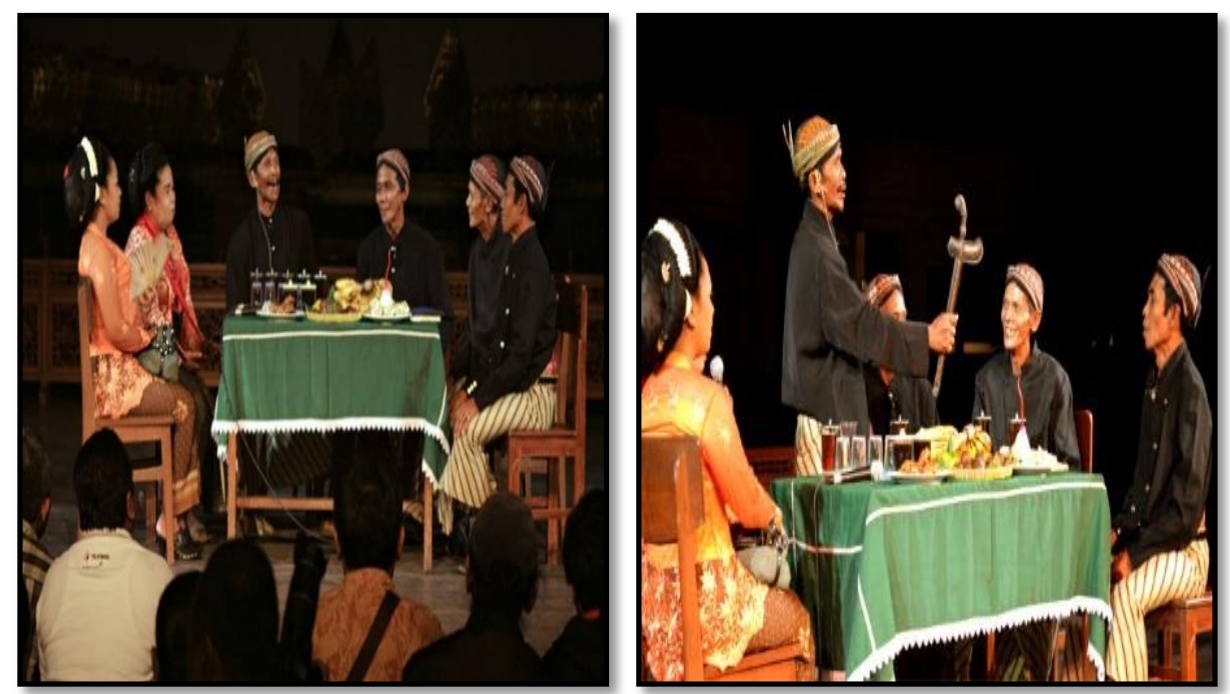

Gambar 1. Bentuk Awal Pertunjukan Jemblung

(Sumber: https://budayajawa.id)

Seni pertunjukan Jemblung adalah bagian dari kehidupan masyarakat Banyumas. Pertunjukan Jemblung dimainkan oleh 4-7 orang yang masing-masing mempunyai peran tertentu yaitu satu orang berperan sebagai dalang, sedangkan lainnya berperan sebagai niyaga, sindhen, dan kadangkala merangkap sebagai tokoh-tokoh dalam alur cerita yang dibawakan. Jemblung menyajikan kisah tentang babad, legenda atau cerita rakyat. Elemen pendukung lainnya yang harus ada dalam pertunjukan Jemblung adalah umborampe berupa sesajen berisi tumpeng, sayuran, bubur merah putih, jajanan pasar, buah-buahan, dan minuman yang ditempatkan dalam sebuah tampah lalu ditempakan di meja besar kemudian pemain Jemblung duduk saling mengelilingi meja tersebut.

Peran dalang sangat vital karena selain sebagai pemimpin, bertindak juga sebagai sutradara yang mengatur jalannya pertunjukan. Hal yang menarik dari kesenian Jemblung adalah para pemain menggunakan beberapa makanan maupun minuman sebagai media komunikasi untuk mendukung suasana cerita dalam setiap adegan. Karakteristik kesenian Jemblung menggunakan makanan maupun minuman untuk merepresentasikan sebuah tokoh dalam cerita serta memfungsikan Jemblung untuk acara ruwatan, menjadi salah satu ciri khas dari Kesenian Jemblung yang tidak dapat ditemukan dalam kesenian lain di Kabupaten Banyumas.

Seiring berjalannya waktu, fenomena berkembangnya teknologi informasi yang menawarkan hiburan yang bersifat modern menyebabkan generasi muda secara khusus dan masyarakat secara umum kurang melestarikan kesenian Jemblung, sehingga berdampak pada penurunan eksistensi kesenian Jemblung. Kondisi tersebut melatarbelakangi salah 
satu seniman dari Banyumas yaitu Agung Wicaksono untuk melakukan reformasi atau perubahan format bentuk penyajian Jemblung. Transformasi dilakukan tanpa merubah pakem yang menjadi ciri khas dalam pertunjukan Jemblung. Perubahan menciptakan realitas baru yang dipengaruhi oleh proses perubahan sosial budaya dalam masyarakat Banyumas.

Tahap awal setelah proses transformasi, pra-pertunjukan tidak jauh berbeda dengan awal kemunculan Jemblung di Kabupaten Banyumas yakni mempersiapkan umborampe. Pada proses pertunjukan pembuka lagu dandanggula cengkok Banyumas masih digunakan sebagai salah satu pakem yang tidak dapat ditinggalkan dalam pertunjukan Jemblung. Lirik lagu dandanggula menceritakan tentang tema dalam pertunjukan. Jejer sepisan digunakan sebagai adegan permulaan terjadinya konflik yang kemudian berkembang menjadi sajian dramatik sesuai dengan sumber cerita. Cerita dibawakan oleh para pemain yang terdiri dari 5-10 orang termasuk didalamnya pemain calung dan dalang. Kostum yang digunakan menyesuaikan dengan tema pertunjukan. Perubahan lain dalam pertunjukan Jemblung adalah waktu, tempat pementasan, iringan, dan fungsi. Waktu pertunjukan dimulai lebih awal yaitu pukul 19.00 dan berakhir pukul 22.00 WIB.

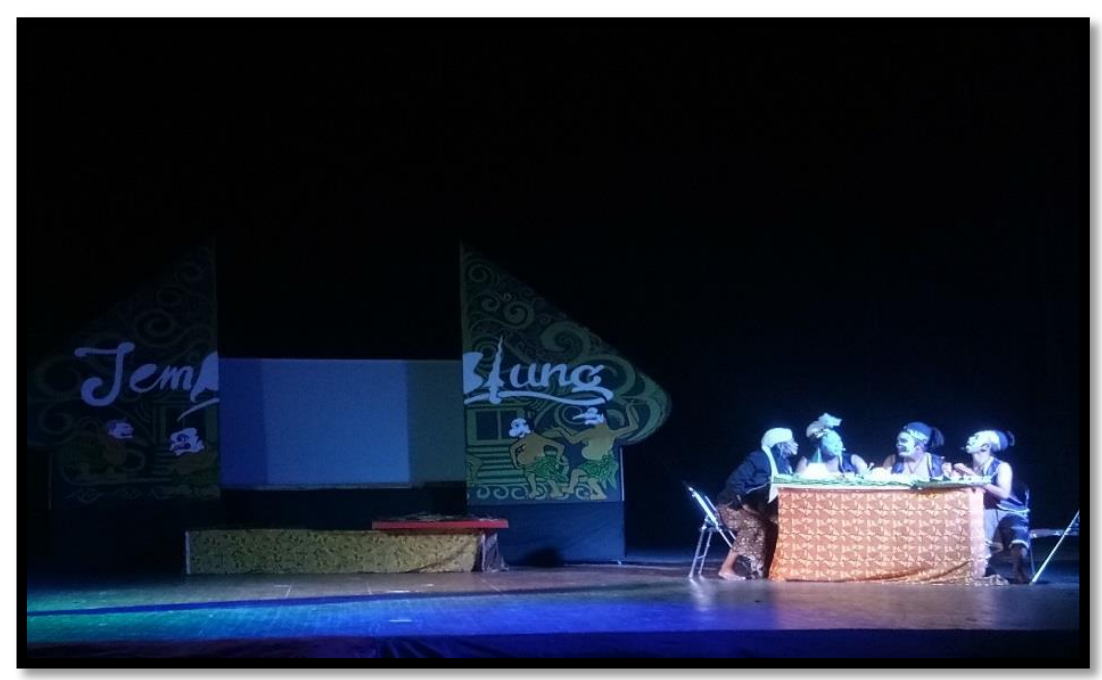

Gambar 2. Perubahan Bentuk Kesenian Jemblung (Dokumentasi: Nurratri Widya Pangestika)

Tempat pementasan tidak lagi diadakan di depan teras rumah warga, lapangan maupun halaman rumah namun dipentaskan di gedung kesenian, pendopo Kabupaten, Kecamatan maupun Balai Warga. Selain pemain, waktu dan tempat pementasan, perubahan dilakukan oleh Sanggar Blakasuta dengan merubah iringan musik yang 
biasanya diiringi mulut para pemain yang dikolaborasikan dengan Calung Banyumas. Cerita dalam pertunjukan Jemblung bukan lagi tentang babad kamandaka, serat menak, dan babad tanah Jawa, melainkan fenomena yang sedang populer di masyarakat Banyumas seperti Bawor Jenggirat, Jaka Pangarep, Bawor Plesir Kayangan, dan Olih Dewandaru. Hal tersebut menjadikan fungsi kesenian Jemblung berubah, dimana awal kemunculan hanya berfungsi sebagai sepasaran bayi, hiburan maupun ruwatan menjadi kritik sosial, hiburan, dan komunikasi.

Penutup pertunjukan Jemblung saat ini tidak ditandai dengan sajian gending lancaran Eling-eling laras slendro pathet manyura melainkan lagu-lagu khas Banyumas yang lain seperti Bendrong kulon maupun Balapan Tengu. Kegiatan berkesenian merupakan kebutuhan yang saling berkaitan satu sama lain antara seorang seniman dengan masyarakat sebagai apresiator. Dalam pemenuhan kebutuhan disela-sela kehidupan kesehariannya, seorang seniman menyempatkan peluang untuk menikmati ataupun berekspresi seni. Perubahan ke dalam bentuk baru yang terjadi bukan semata-mata karena perubahan yang ditimbulkan dari cara hidup manusia tetapi dapat pula karena manusia pendukung kebudayaan daerah itu sendiri telah berganti generasi. Tanpa adanya tindakan pembaharuan maka kesenian tradisional akan mengalami kepunahan. Oleh karena itu, dibutuhkan suatu upaya, baik berupa perubahan atau pengembangan di dalam kesenian tradisonal sebagai bentuk pengaktifan kembali agar tetap diterima oleh masyarakat.

\section{Metode Penelitian}

Penelitian ini menggunakan metode kualitatif interpretatif yang artinya adalah penelitian yang bersifat deskripsi, tidak menggunakan angka-angka, dan mendeskripsikan berupa ucapan, tulisan, dan pengamatan. Melalui metode penelitian kualitatif, akan dijelaskan terkait fenomena masalah yang dikaji lalu dikaitkan dengan kondisi alam atau fisik dan kondisi lingkungan sosial budaya pada tempat permasalahan dari lingkungan pemilik kesenian. Sumber-sumber yang dimungkinkan oleh penulis untuk mendapatkan informasi atau data yang dibutuhkan dalam sebuah penelitian yaitu data primer yang meliputi wawancara dan pengamatan mengenai kesenian Jemblung, dan data sekunder diperoleh dari dokumen dan arsip mengenai kesenian Jemblung serta dokumen visual berupa video dan foto yang menggambarkan kondisi kesenian Jemblung dari dinas pariwisata dan kebudayaan Banyumas maupun peneliti sebelumnya. Teknik pengumpulan data terdiri dari observasi, wawancara, dan studi dokumen. 
Pada proses pengabsahan data dalam penelitian ini menggunakan kriteria derajat kepercayaan (kredibilitas). Selain itu, untuk menjaga kedapatpercayaan dalam penelitian ini menggunakan teknik triangulasi sumber, sedangkan teknik analisis data yang digunakan mengacu pada Miles dan Hubermen yang diterjemahkan oleh Rohidi (2011, p. 240) yaitu proses analisis dilakukan dengan model siklus mulai dari pengumpulan data, reduksi dan mengklarifikasi, menyimpulkan dan menginterpretasikan semua informasi secara selektif.

\section{Seni sebagai Komunikasi Emosi}

Komunikasi merupakan cara bagaimana seseorang melakukan sebuah interaksi antara satu dengan lainnya. Jika karya seni dibuat sebagai bentuk komunikasi, maka dalam proses penciptaan sang seniman sedang melakukan encode atau pengkonstruksian pesan. Asumsi pertama teori seni Tolstoy adalah seni merupakan bentuk komunikasi. Proses komunikasi dalam sebuah pertunjukan, membentuk sebuah interaksi yang disampaikan menggunakan simbol sehingga terciptalah makna yang akan disepakati bersama, baik dari pemain maupun penonton. Untuk disebut sebagai sebuah seni, tidak cukup hanya dikatakan bahwa seniman mengekspresikan emosi, tetapi juga harus mengandung makna mengkomunikasikan emosi, aktivitas seni semacam aktivitas bahasa yang menyatukan manusia dalam emosi (Stolnitz, 1960, p. 173).

Secara umum emosi bersifat subjektif dan terkait dengan senang (pleasant) atau tidak senang (unpleasant) terhadap sesuatu. Pengalaman estetis bersifat emosional yang diawali dengan proses kognitif dan disertai gerakan tertentu. Menurut Junaedi (2017, p. 102) pengalaman estetis dapat berupa emosi estetis formalistis, dimana kemenarikan yang terasa dalam emosi estetis formalistis semata-mata berupa rasa menyenangkan (positif) yang ditimbulkan oleh susunan atau komposisi bentuk dari objek estetis tanpa disertai empati kesedihan. Karya seni dapat menyebabkan penonton maupun pendengar memasuki hubungan komunikasi estetis, tidak terkecuali pada sajian pertunjukan Jemblung Banyumas.

Penonton dalam pertunjukan Jemblung merupakan kehormatan bagi seorang pengrawit yang memberikan dorongan luar biasa sehingga menjadikan permainannya semakin maksimal. Penonton dapat menikmati pertunjukan Jemblung dengan cara dan kemampuannya masing-masing sesuai pengalaman estetis dalam menikmati sajian. Respon berupa candaan, komentar, senggakan bahkan mengikuti jalannya pertunjukan dengan para pemain Jemblung membentuk sebuah hubungan komunikasi. Hal tersebut sesuai dengan 
pemikiran Tolstoy yang menjelaskan bahwa definisi seni sebagai alat komunikasi mengandung dua unsur yaitu ungkapan (expression) dan kerasukan (infection) (Jahn, 1975). Ekspresi merupakan proses di mana apa yang berada dalam dunia subjektif seniman yaitu perasaannya menjadi mewujud dalam bentuk yang biasa diakses orang lain, sedangkan kerasukan merupakan proses di mana ekspresi seniman diasimilasi oleh orang lain (Sunarto, 2009, p. 70).

Ungkapan (expression) dan kerasukan (infection) terlihat ketika sajian pertunjukan Jemblung berlangsung, terdapat sebuah stimulus dan respon yang bersifat estetis formalistis dimana karya seni sebagai salah satu jenis objek estetis menimbulkan rasa menyenangkan seperti pada gambar 3 antara penonton dengan pemain Jemblung, hal tersebut ditandai dengan adanya interaksi menggunakan beberapa simbol. Kusumastuti (2006, p. 2) mengatakan bahwa proses berlangsungnya sebuah pertunjukan terjadi sebuah interaksi simbolik antara penonton dan pemain yang disampaikan melalui simbol-simbol tertentu, sebab esensi interaksi simbolik terletak pada komunikasi melalui simbol-simbol yang bermakna. Dalam pertunjukan Jemblung, simbol interaksi komunikasi antara penonton dengan pemain Jemblung adalah senggakan. Senggakan merupakan vokal bersama atau tunggal saling bersahut-sahutan dari para pemain gendhing dengan pemain Jemblung menggunakan parikan (pantun) yang berfungsi untuk mendukung terwujudnya suasana ramai dalam sajian suatu gendhing.

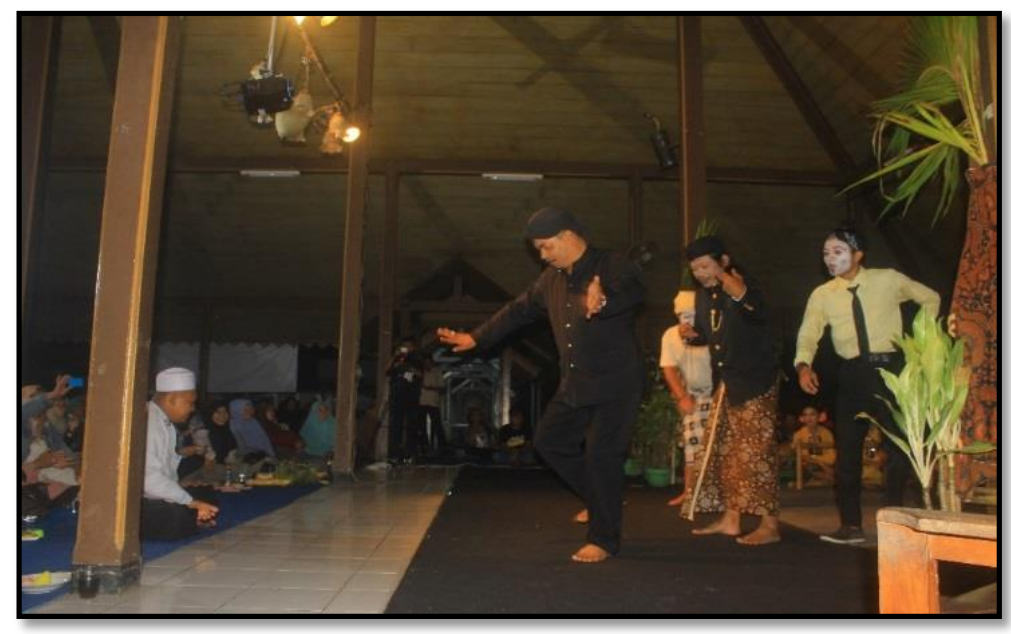

Gambar 3. Interaksi Penonton dan Pemain Jemblung (Dokumentasi: Nurratri Widya Pangestika)

Karakteristik senggakan dalam Jemblung terdapat pada gendhing-gendhing yang dimainkan oleh pemain dan selalu diucapkan oleh sinden sebagai bentuk komunikasi pemain dengan penari lengger maupun penonton. Tolstoy (1969, p. 197) mengungkapkan 
bahwa komunikasi gagasan dianggap berhasil ketika orang lain memahaminya, dan komunikasi perasaan dianggap berhasil ketika orang lain dapat merasakan perasaan tersebut. Keberhasilan komunikasi dalam pertunjukan Jemblung terlihat ketika para pemain dan penonton saling berinteraksi satu sama lain. Senggakan yang digunakan dalam gendhing Banyumasan terdapat dalam gendhing bendrong kulon. Jenis senggakan yang digunakan adalah Senggak nglagu, merupakan jenis senggak dengan menciptakan alur lagu tertentu sesuai dengan sajian gendhing seperti pada penggalan notasi berikut.

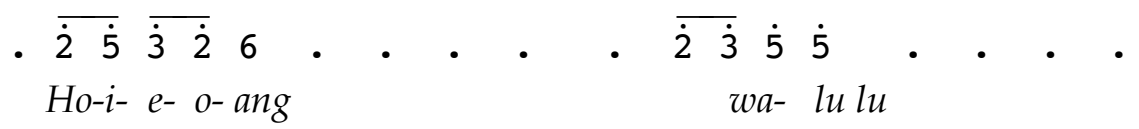

Senggak dalam penyajian bendrong kulon memiliki kesan rasa ramẻ. Hal tersebut senada dengan pernyataan Budiarti (2008, p. 74) yang mengatakan bahwa kedudukan senggakan di dalam gendhing-gendhing Banyumasan merupakan gendhing vokal sehingga tanpa senggak pertunjukan akan terasa sepi. Laras yang digunakan dalam gendhing bendrong kulon adalah laras slendro dengan pathet sanga dan berirama lancar. Berikut struktur balungan gendhing Bendrong Kulon.

\section{Bendrong Kulon}

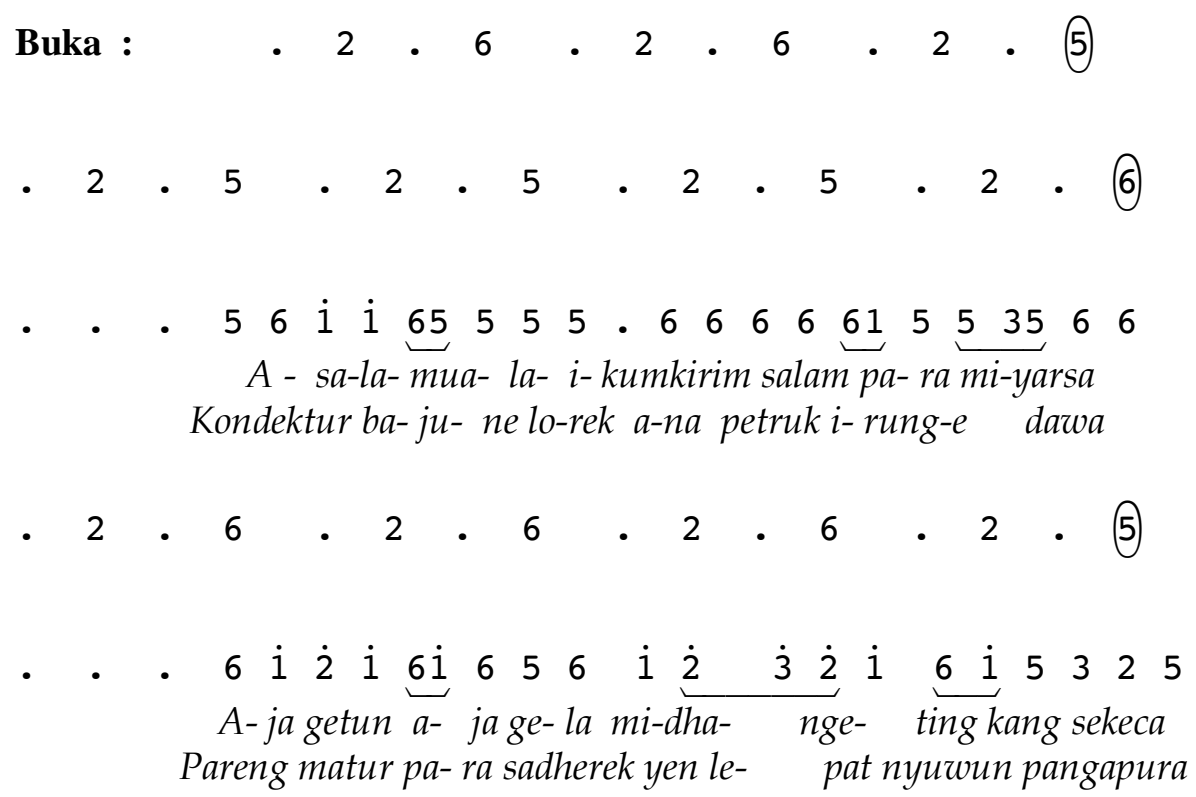




\section{Bentuk inovasi vokal dari Blendrong Kulon}

$$
\begin{aligned}
& \begin{array}{llllllllllllllll}
3 & 2 & 3 & 5 & 3 & 2 & 3 & 5 & 3 & 2 & 3 & 5 & 3 & 2 & 1 & 6
\end{array}
\end{aligned}
$$

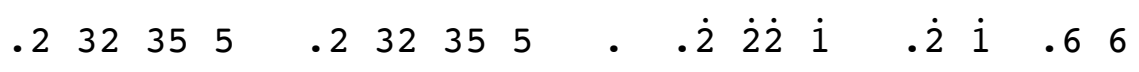

$$
\begin{aligned}
& \text { Arum-arum manis arum-arum manis arum manis gula jawa } \\
& \begin{array}{llllllllllllllll}
3 & 2 & 1 & 6 & 3 & 2 & 1 & 6 & 3 & 2 & 1 & 6 & 3 & 2 & 3 & 5
\end{array}
\end{aligned}
$$

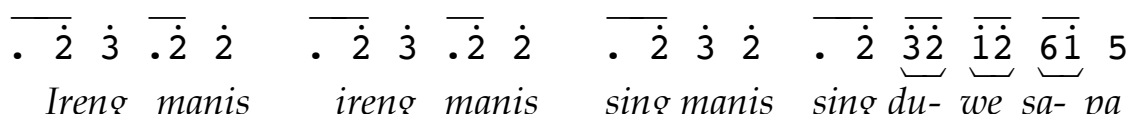

\section{Senggakan}

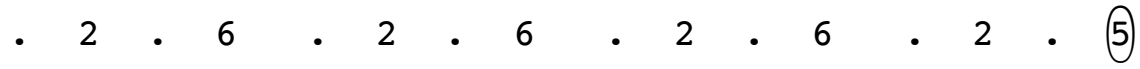

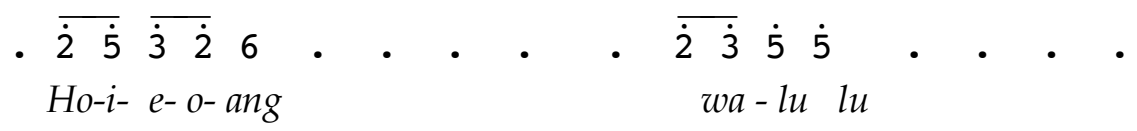

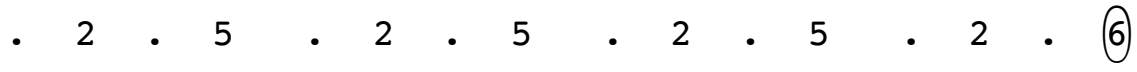

$$
\begin{aligned}
& \text { - } \overline{\dot{2} \dot{3}} \overline{\dot{2}} \underbrace{\dot{2} \overline{3} \cdot \overline{5}} \overline{55} 5 \text {. } \overline{. \overline{2} \dot{3}} \overline{\dot{5} \dot{3}} \cdot \overline{6} \overline{66} 6 \\
& \text { So-la-li-la-li a-so-la-li sola lilah a-so-la-li }
\end{aligned}
$$

Gambar 4. Notasi Gendhing Bendrong Kulon

(Transkip: Aji, 2018)

Ekspresi estetis dalam karya seni Jemblung dapat diinterpretasikan melalui sebuah sajian pertunjukan serta dari struktur iringan musik yang dihasilkannya. Seniman menciptakan karya seni yang memungkinkan bagi masyarakat untuk berpartisipasi dan partisipasi masyarakat sebagai penikmat atau penonton telah menimbulkan adanya komunikasi. Simbol senggakan selain untuk menarik respon penonton, juga digunakan untuk memberi ruang interaksi antar pemain Jemblung dengan penari lengger seperti yang dapat dilihat pada gambar 5 . 


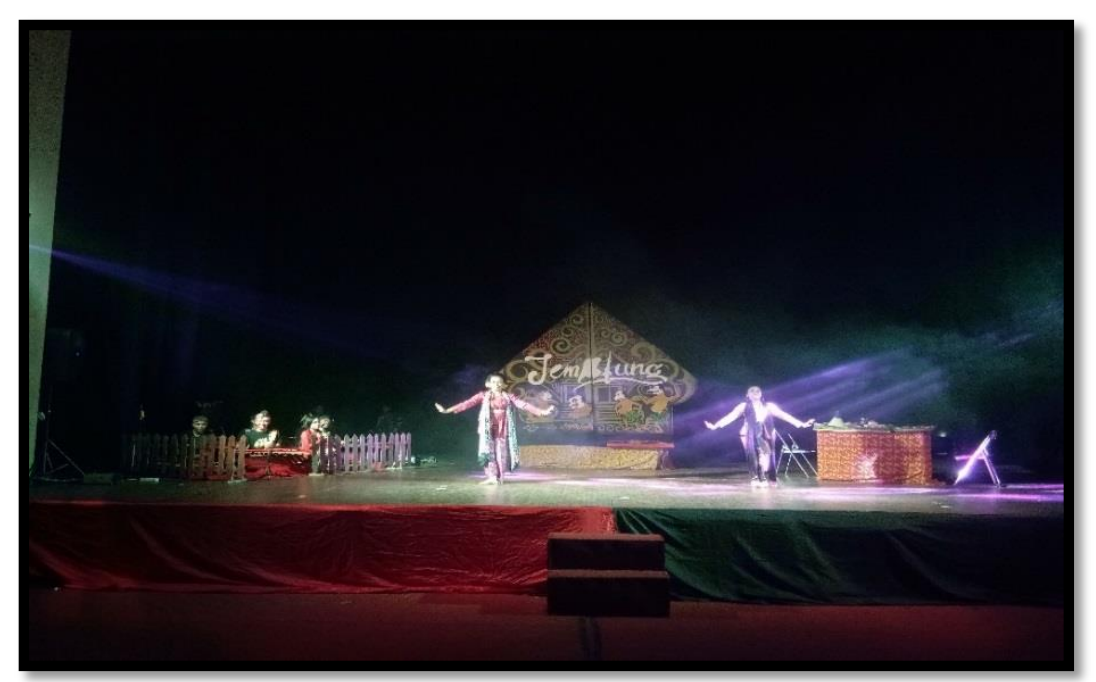

Gambar 5. Lengger Dalam Pertunjukan Jemblung

(Dokumentasi: Nurratri Widya Pangestika)

Dengan demikian, dalam pemikiran Tolstoy tentang ekspresivisme, hakiki sebuah seni yang dikemukakan dalam asumsi yang pertama dan kedua tentang satu bentuk komunikasi seni dimana feeling atau perasaan seniman dalam menciptakan sebuah karya telah dapat dibuktikan melalui sajian pertunjukan Jemblung dengan sebuah simbol interaksi komunikasi yaitu senggakan.

\section{Seni Baik dan Seni Buruk}

Seni pertunjukan Jemblung sebagai media komunikasi menampilkan bentuk-bentuk ekspresif yang perlu diterjemahkan dan diinterpretasikan sebagai kontrol perilaku. Pertunjukan Jemblung tidak hanya sekedar menghadirkan visual saja, akan tetapi juga dapat memberikan nilai atau pesan-pesan moral kepada penonton yang digunakan sebagai kontrol perilaku dalam kehidupan bermasyarakat di Kabupaten Banyumas. Dalam pemikiran Tolstoy (Sunarto, 2009, p. 190), seni yang baik bukan hanya menjadi bahasa universal tetapi sekaligus menjadi bahasa moral, karena dengan seni manusia menjadi lebih beradab dan santun. Dari sudut estetis, seni yang baik harus menyenangkan setiap orang untuk mengaksesnya dan dari sudut moral seni dapat menyatukan manusia dalam moralitas religius.

Ide garap dalam penciptaan naskah cerita yang mengandung moralitas dalam kesenian Jemblung dapat hadir, dijumpai atau terjadi di kehidupan sehari-hari dengan melibatkan fenomena-fenomena tertentu seperti fenomena alam dan sosial budaya. Seperti dalam petikan naskah cerita Olih Dewandaru. Proses karya cipta pada cerita Olih 
Dewandaru dilatarbelakangi fenomena budaya masyarakat tentang kepemimpinan yang selalu berkaitan dengan dewandaru. Simbolisasi dewandaru dalam masyarakat Jawa berbentuk wadag berupa gumpalan cahaya yang muncul menuju seseorang yang dipercaya oleh Tuhan untuk menjadi seorang pemimpin.

Seseorang yang mendapatkan dewandaru adalah yang memegang kekuasaan/ politik, sementara fakta yang ada bahwa dalang merasa resah dengan keadaan Banyumas sebagai Kabupaten yang terkenal dengan daerah kaum intelektual dan kaya raya namun tidak ada satupun calon pemimpin yang menjadi kandidat di Kabupaten Banyumas. Hal tersebut menjadi alasan mengapa tema Olih Dewandaru diangkat menjadi sebuah cerita masa kini karena sebagai bagian dari revitalisasi kesenian Jemblung. Di dalam Olih Dewandaru penyampaian masalah moralitas melalui kritik sosial terasa halus, yang dapat dilihat dalam penggalan kutipan adegan oleh dalang berikut ini.

... Purwokerto kota satria. Ilmu tanpa agama buta, agama tanpa ilmu cilaka. Siki pancen
jamane jaman edan, nek ora edan ora keduman, tapi seedan edane menungsa, lewih becik sing
eling lan waspada. Lha dha lah! Nang tlatah sing diileni kali serayu, sing adoh ratu cedak
watu, urip miline labuh ora urup. Menungsa sing makmur, labuh pada ora akur. Sawah subur
kebanjur mandul, sing ditandur pari tukule malah perumahan. Sing diuri-uri labuh ora lestari,
sing kudune lestari siki labuh dibasmi. Ngomong cablak jere kepenak, tapi bocah siki gengsi
nek diomong cowag. Ngomong cablak be labuh terkucil, apa maning ngomong karo bahasa
krama inggil? Aduh biyung aduh Gusti, kepriwe bahasa arep lestari? Gunung Slamet
sejroning ati kudu diuri-uri, siki malah dibabad-dibasmi nggo pembangkit listrik tenaga bumi.
Lha dha lah! Menungsa labuh mambu prengus! Pemerintah kurang mengurus, mula sebab
masyarakat mengendus curiga. Ana pageblug apa ndaru? wit ringin sing umure ratusan taun
rubuh ... mangga kaya ngapa. Terjemahan:

... Purwokerto kota satria. Ilmu tanpa agama buta, agama tanpa ilmu celaka, sekarang memang zaman sudah gila, kalau tidak gila tidak akan mendapatkan bagian, tetapi segila-gilanya manusia, lebih baik sadar dan waspada. Lha dha lah! Di daerah yang dilewati sungai Serayu, jauh dari bebatuan, kehidupan tidak dapat dikalahkan. Manusia yang makmur, mulai tidak akrab. Sawah yang subur dan tidak lagi subur, dikelilingi oleh rumah-rumah. Yang dilestarikan sudah tidak lestari, yang harus berkelanjutan telah luluh. Bicara cablak itu mudah, tetapi anak zaman sekarang tidak mau dikatakan cowag. Bicara cablak mulai tersingkir apalagi berbicara bahasa inggil? aduh biyung aduh gusti, bagaimana bahasa akan lestari? Gunung Slamet harus dilestarikan, meskipun telah dihancurkan oleh pembangkit listrik bumi. Lha dha lah! Manusia bau prengus! Pemerintah tidak mengikuti karena publik curiga. Apakah kamu menemukannya? Anda tahu bahwa ratusan tahun telah jatuh ... mari kita saksikan.

Kutipan dalam adegan di atas dapat dipahami bahwa melalui kesenian Jemblung, dalang menciptakan sebuah sastra yang mengangkat persoalan-persoalan realitas yang ada di masyarakat. Dalang memberikan makna yang kritis serta nilai moral melalui penciptaan teks drama, dimana hal itu menjelaskan bahwa perkembangan budaya pada masyarakat Banyumas semakin terkikis oleh arus globaliasi. Dewandaru masih tetap menjadi bagian dari budaya adiluhung yang dipercaya akan melahirkan manusia-manusia pilihan untuk 
menegakkan kebenaran, keadilan, dan kemakmuran bangsa.

Perubahan sosial berdampak pada krisis multidimensi dalam bidang pertahanan dan keamanan, lingkungan, hak asasi manusia, sosial budaya, moral, dan pendidikan. Krisis moral mengungkapkan kondisi mental yang mengkhawatirkan dan karakter ditunjukkan melalui banyaknya perilaku menyimpang yang tidak konsisten dengan nilai-nilai karakter mulia dan tatanan hukum positif. Sehingga dengan mempelajari kesenian Jemblung sejak dini dapat berfungsi sebagai upaya untuk memperkenalkan, memahami serta mewarisi nilai-nilai karakter lokal dan menanamkan nilai-nilai budayanya. Proses pembudayaan ini tidak dapat hanya mengharapkan guru kesenian saja sebagai media penyampaian materi, oleh sebab itu menghadirkan seniman kesenian tradisional untuk mengajar di sekolahsekolah adalah salah satu alternatif. Seperti terlihat pada gambar 6, ketika Agung Wicaksono selaku dalang Jemblung memberikan pemahaman dan materi tentang kesenian Jemblung kepada siswa-siswi di salah satu sekolah dasar di Kabupaten Banyumas.

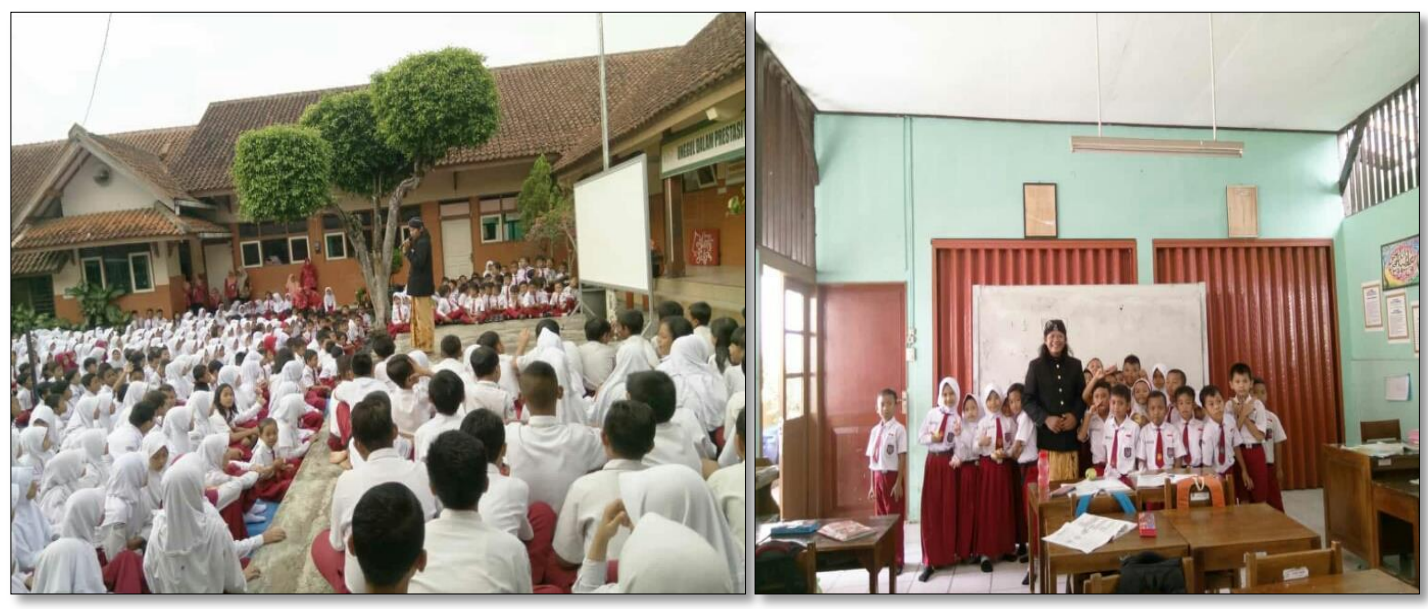

Gambar 6. Proses Penanaman Karakter oleh Dalang Jemblung (Dokumentasi: Nurratri Widya Pangestika)

Melaui pendidikan serta anak-anak sebagai sasaran subyek pewarisan kesenian tradisional sehingga keberlangsungan kesenian-kesenian tradisional termasuk Jemblung akan selalu mendapatkan apresiasi yang baik. Seperti yang disampaikan dalang Jemblung bahwa kesempatan tersebut dimanfaatkan dengan baik, melalui pemberian materi tentang kesenian Jemblung, seperti misalnya memberikan beberapa cerita yaitu Punakawan Zaman Now dan Sang Panutan yang bertujuan untuk menanamkan karakter yang baik melalui pemahaman tentang tokoh-tokoh yang memiliki sifat moralitas religius, gigih, berani, kuat, berjiwa kepemimpinan, tanggung jawab dan berbagai dimensi karakter positif, sehingga dalang mengharapkan anak-anak dapat menjadi penerus keberlangsungan 
kesenian tradisional di Banyumas termasuk melalui pembelajaran dalam kesenian Jemblung.

\section{Kesimpulan}

Perubahan kesenian Jemblung erat kaitannya dengan aspek-aspek pendukung di dalam kesenian. Pandangan ekspresivisme berkaitan dengan komunikasi dan emosi yang disampaikan oleh seniman saat pertunjukan Jemblung agar dapat dirasakan oleh pemain maupun penonton. Nilai atau pesan-pesan moral dalam pertunjukan Jemblung dapat ditemukan melalui cerita-cerita yang digunakan sebagai kontrol perilaku dalam kehidupan bermasyarakat sebagai upaya untuk memaknai hidupnya. Makna hidup merepresentasikan tingkat pemahaman paling tinggi yang dapat diraih manusia yaitu tentang kebaikan.

\section{Kepustakaan}

Blocker. (1979). Philosophy of Art. New York: Charles Scribner's Sons.

Budiarti, M. (2008). Sekilas tentang Sindhenan Banyumasan. Keteg Jurnal Pengetahuan, Pemikiran, Kajian Tentang BunyiJurnal Pengetahuan, Pemikiran, Kajian Tentang Bunyi, 8(1), 70-82.

Harwanto, D. C. (2018). Memaknai Inkulturasi Dalam Pendidikan Seni Dan Konservasi. Tonika: Jurnal Penelitian Dan Pengkajian Seni, 1(1), 40-50.

Jazuli, M. (2016). Proceding Seminar Nasional Seni Pertunjukan dan Pertunjukan Seni. Optimalisasi Seni Pertunjukan Tradisional Dalam Jagat Pendidikan Seni, 34-49. Semarang: Universitas Negeri Semarang.

Junaedi, D. (2017). Estetika Jalinan Subjek, Objek, dan Nilai (D. ; S. Riwayanto, ed.). Yogyakarta.

Kusumastuti, E. (2006). Laesan sebuah Fenomena Kesenian Pesisir: Kajian Interaksi Simbolik antara Pemain dan Penonton. Harmonia - Jurnal Pengetahuan Dan Pemikiran Seni, VII(3), 1-10.

Rohidi, T. R. (2011). Metodologi Penelitian Seni. Semarang: Cipta Prima Nusantara, C.V.

Sheppard, A. (1987). Aesthetics. In Oxford University Press. Oxford\&New York.

Stolnitz, J. (1960). Aesthetics and Philosophy of Art Criticism.

Sunarto. (2009). Seni sebagai ekspresi emosi (Hakiki, Telaah Seni, Nilai Hakiki, Abstrak Kunci, Kata Ada, Pendahuluan). 1, 1-14.

Tolstoy, L. (1969). What is Art and Essays on Art. London. 